\section{Conservation Horticulture for Yarey Palm and Buccaneer Palm: Substrate and Sowing Depth Affect Germination and Early Seedling Growth}

\author{
Vickie Murphy ${ }^{1,5}$, Teodoro Clase ${ }^{2}$, Rosa A. Rodríguez-Peña ${ }^{2,3,4}$, \\ Francisco Jiménez-Rodríguez ${ }^{2}$, Brett Jestrow ${ }^{4}$, Chad E. Husby ${ }^{4}$, \\ and M. Patrick Griffith ${ }^{1}$
}

\begin{abstract}
Additional index words. Arecaceae, container cultivation, Copernicia berteroana, Pseudophoenix sargentii, seed treatment

Summary. Palms (Arecaceae) are perhaps the most important tropical plant family for human use, both for utility and ornamental horticulture. The wide diversity of palm species with different seed germination characteristics necessitates tailoring horticultural practices to the needs of each. This is crucial for production and conservation horticulture. In this study, wild-collected seeds of yarey palm (Copernicia berteroana) and buccaneer palm (Pseudophoenix sargentii) were germinated in a variety of organic (standard nursery container mixes) and inorganic substrates. The yarey palm seeds were sown at two different depths, 0.5 inch and at the surface (seed half exposed). Mean maximum germination across all treatments for yarey palm was $79 \%$ and for buccaneer palm $60 \%$. The standard nursery mixes generally fostered the best germination and long-term survival. This is likely due to a combination of the lower water availability at the surfaces of the more porous inorganic substrates (sand and perlite) and greater difficulty for coarse palm roots to penetrate the denser inorganic substrates, including fired ceramic, which otherwise had similar water-holding capacity (WHC) and even lower air space than the organic substrates. Difficulty of penetration caused roots of some seedlings to either dry up early in germination as in the surface sown yarey palm, or to "push up" the seed (buccaneer palm) rather than penetrating the substrate and this was often fatal. Thus, inorganic substrates are not recommended for germination and early seedling growth of these palm species and planting the seeds slightly below the surface may be preferable to surface sowing. For conservation horticulture of wild-collected palm seeds, this information can help prevent further genetic bottlenecks while under protective cultivation.
\end{abstract}

$\mathrm{P}$ alm horticulture makes some of the most beautiful, useful, and emblematic tropical plants

We thank Montgomery Botanical Center for providing support for carrying out the experiments. We also thank Lin Lougheed and Montgomery Botanical Center for supporting field collection of seeds and volunteers Christiane Tyson, Lane Park, Maria Raymund, Trish Hicks, Margaret Martin, Cecilia Thornton, Elaine Jennings Sabatino, and Marian Jennings Brusberg who assisted with data collection.

Mention of a trademark, proprietary product, or vendor does not constitute a guarantee or warranty of the product by Montgomery Botanical Center and does not imply its approval to the exclusion of other products or vendors that also may be suitable.

${ }^{1}$ Montgomery Botanical Center, 11901 Old Cutler Road, Coral Gables, FL 33156

${ }^{2}$ Jardín Botánico Nacional, Avenida República de Colombia, Santo Domingo, Distrito Nacional, Dominican Republic

${ }^{3}$ Department of Biological Sciences, Florida International University, 11200 SW 8th Street, Miami, FL 33199

${ }^{4}$ Fairchild Tropical Botanic Garden, 10901 Old Cutler Road, Miami, FL 33156

${ }^{5}$ Corresponding author. E-mail: vickiem@montgomerybotanical.org.

doi: 10.21273/HORTTECH03521-16 available to the world. Horticulture also provides a viable means of conserving palm genetic diversity (Fotinos et al., 2015) even when this was not the original intent (Asmussen-Lange et al., 2011). As few as 15 individuals grown from seed from a wild palm population can capture $80 \%$ or more of the genetic diversity in the original population (Namoff et al., 2010), though life history and breeding system should be taken into account when formulating a collecting strategy to maximize genetic capture (Griffith et al., 2015). Furthermore, horticulture can reduce collecting pressure on wild populations by making desirable plants available to the public (Kay et al., 2011). Collecting seeds is only the first step in establishing a palm in cultivation for beauty and conservation. The seeds must then be successfully germinated and the seedlings grown on.

Substrate has been found to be crucial in the germination of palm and cycad (Cycadales) seeds (Calonje et al., 2010; Murphy et al., 2013). Among the substrates that have proven most useful, aside from standard peat-based nursery mixes, are calcined clays and coarse sand. Fired ceramics of calcined montmorillonite clay have high cation exchange capacity (Warren and Bilderback, 1992). Sand is one of the most versatile inert substrates and has long been used as a stand-alone substrate in research (Hewitt, 1966), and is one of the most frequently used amendments in container substrates (Gartner, 1981). Sowing depth has also been found to significantly affect palm germination. Broschat and Donselman (1986) found that a sowing depth of $1 \mathrm{~cm}$ resulted in significantly increased germination percentage of golden cane palm (Dypsis lutescens) compared with either surface sowing, or depths greater that $1 \mathrm{~cm}$. This result was related to the drying potential of the germination site, as differential shade treatments increased germination at shallower depths (Broschat and Donselman, 1986).

We chose to investigate germination of wild-collected seeds of two imperiled palm species native to Hispaniola. Yarey palm is imperiled by illegal extraction of mature individuals, arson, and habitat loss (Veloz et al., 2013). Buccaneer palm is confined to the far east of the Dominican Republic, where some of the populations have been extirpated for tourism development and trade (RodríguezPeña et al., 2014). In both cases, ex situ cultivation is an essential part of integrated conservation efforts, ensuring maintenance of genetic diversity for future introduction (Namoff

\begin{tabular}{llll}
\hline $\begin{array}{l}\text { Units } \\
\begin{array}{l}\text { To convert U.S. to SI, } \\
\text { multiply by }\end{array}\end{array}$ & U.S. unit & SI unit & $\begin{array}{l}\text { To convert SI to U.S., } \\
\text { multiply by }\end{array}$ \\
\hline 3.7854 & gal & $\mathrm{L}$ & 0.2642 \\
2.54 & inch $(\mathrm{es})$ & $\mathrm{cm}$ & 0.3937 \\
28.3495 & $\mathrm{Oz}$ & $\mathrm{g}$ & 0.0353 \\
$\left({ }^{\circ} \mathrm{F}-32\right) \div 1.8$ & ${ }^{\circ} \mathrm{F}$ & ${ }^{\circ} \mathrm{C}$ & $\left({ }^{\circ} \mathrm{C} \times 1.8\right)+32$
\end{tabular}

Hortlechnology · December $201626(6)$ 
et al., 2010), and also providing a germplasm source that can alleviate the need for extractive harvest (Kay et al., 2011). The first step in successful ex situ conservation is the propagation of properly collected seed. Thus, the aim of this study was to assess how different substrates of both organic and inorganic nature affect the germination and early growth of palm seedlings with different germination requirements and germination time frames. Yarey palm seeds generally do not require any scarification and germinate within a few months. In contrast, buccaneer palm seeds benefit from endocarp removal (Riffle et al., 2012) and germinate over a period of many months.

\section{Materials and methods}

YAREY PALM EXPERIMENT. We sought to evaluate the effects of media choice and sowing depth on an imperiled palm species in an experiment that ran from 1 Nov. 2013 to 12 June 2014. Seeds of yarey palm $(\mathrm{n}=$ 1008) were collected from two wild mother plants near Puerto Plata, on the north coast of the Dominican Republic in Oct. 2013. Seeds were cleaned in the field and then were imported to Montgomery Botanical Center (MBC, Coral Gables, FL). Seeds were soaked in water for $1 \mathrm{~d}$ and then randomly allocated to $5-\mathrm{L}$ treatment pots (Poly-Tainer 2B; Nursery Supplies, Chambersburg, $\mathrm{PA})$ of either potting medium (Promix BX; Premier Tech Horticulture, Quakertown, PA) or coarse silica sand $(6 / 20$ grade; Florida Silica Sand Company, Fort Lauderdale, FL) and either buried 0.5 inch below the surface or half-buried in the substrate with the top half of the seed exposed. The pots were placed on a plastic bench in a large production greenhouse with overhead irrigation. The experiment was arranged as a twofactor (substrate $\times$ sowing depth) factorial with a randomized complete block design. Blocks were aligned perpendicular to the long axis of the greenhouse to account for any temperature or other environmental gradients from the center of the bench to the edge toward the north end. The greenhouse exhaust fans are along the long axis of the greenhouse and thus air movement was parallel to the blocks. Ambient temperature in the greenhouse was kept between 65 and $85^{\circ} \mathrm{F}$ over the course of the experiment. There were eight blocks consisting of four pots each, with each pot having one of the four possible treatment combinations. Seeds $(\mathrm{n}=$ 25 ) were sown in each pot, so a total of 800 seeds were used in the experiment ( 8 blocks $\times 4$ pots $\times 25$ seeds / pot). Plants were watered with purified (via reverse osmosis) water daily and fertilized once after observable germination with $60 \mathrm{~g}$ of $18 \mathrm{~N}-2.6 \mathrm{P}-$ $6.6 \mathrm{~K}$ slow-release fertilizer (Nutricote Total 360 Day; Florikan, Sarasota, FL). On 12 Feb. 2014 (104 d after sowing), germination (as evidenced by root emergence), and leaf emergence were assessed. On 12 June 2014 (224 d after sowing), number of surviving seedlings and number of leaves per surviving seedling were assessed.

BuCCANEer PALM EXPERIMENT. To further evaluate substrate effects on germination of an imperiled palm species, we ran another experiment. Seeds of buccaneer palm $(n=2113)$ were collected from five wild mother plants on Saona Island, Playa del Canto, in Dec. 2012. Seeds were cleaned in the field and then were imported to MBC. Seeds were dried for 2 weeks and the stony endocarp cracked and removed following the recommendation of Riffle et al. (2012). The seeds were then randomly allocated to plastic pots ( 1.25 gal Poppelmann TEKU; Poppelmann Plastics USA, Claremont, NC) with either a potting mix (Fafard \#2; Conrad Fafard, Agawam, MA), perlite (W.R. Grace \& Co., Cambridge, MA), ceramic (Profile; Profile Products, Buffalo Grove, IL), or coarse silica sand (6/20 grade; Florida Silica Sand Company). The pots were placed on a plastic bench in a large production greenhouse with overhead irrigation. The experiment was arranged as a completely randomized design. Twenty-five seeds were sown in each of 72 pots (1800 seeds were used in the experiment). Seeds and plants were watered with purified (via reverse osmosis) water daily and fertilized once after observable germination with $60 \mathrm{~g}$ of $18 \mathrm{~N}-2.6 \mathrm{P}-$ $6.6 \mathrm{~K}$ slow-release fertilizer (Nutricote Total 360 Day).

After 8 months (13 June 2013 to 18 Feb. 2014) germination, as evidenced by root emergence, was assessed, along with whether leaves were visible and whether the seed had been "pushed up" (i.e., whether root emergence had pushed the seed above the surface of the substrate rather than penetrating the substrate). In addition, length of the longest leaf of each seedling was measured on 30 Mar. 2014.

SUBSTRATE PHYSICAL PROPERTIES (воTH EXPERIMENTs). Airspace, WHC, and total porosity were measured on a volume basis (Danielson et al., 1986). Plastic containers were used for testing (1.25 gal Poppelmann TEKU). The container volume was measured and it was then filled with substrate and weighed to determine dry weight. Water was added until all pore spaces were filled. Water was then drained off and the volume measured. Substrates were then weighed immediately, oven dried, and then weighed again. These measurements were used to determine WHC, air space, and total porosity as percentages, in this manner: air space $=$ volume of drained water $/$ container volume; $\mathrm{WHC}=($ weight of substrate before drying - weight of substrate after drying)/container volume; total porosity = air space + WHC. Three replicates for each substrate were averaged.

Statistical analyses (вотH EXPERIMENTS). Data were analyzed using JMP software (version 11.2.0; SAS Institute, Cary, NC). For count response data such as number of germinated seeds, surviving individuals (i.e., yarey palm), or leafless individuals (i.e., buccaneer palm), a generalized linear model was used with a binomial distribution, a logit link function, and an overdispersion parameter estimated by Pearson chi square/df. The estimation method was Firth adjusted maximum likelihood (Kosmidis and Firth, 2009).

For continuous response data, parametric analysis of variance (ANOVA) models were used with least square means estimates: 1) leaves per surviving seedling of yarey palm, 2) mean length of longest leaf of buccaneer palm seedlings (transformed using the natural logarithm to homogenize the residual variances), and 3 ) substrate physical properties. A Tukey's honestly significant 
difference multiple comparison post hoc test was performed to compare effects of different experimental factors when the overall model was significant.

\section{Results}

YAREY PALM EXPERIMENT. Seeds sown in potting medium at 0.5 -inch depth showed greatest percent germination $(79.5 \%)$, and seeds sown at any depth in potting medium showed greatest number of visible leaves, an average of 2.8 per seedling. In contrast, seeds sown at surface in sand showed lowest germination $(2.0 \%)$, and only an average of 1.38 visible leaves per seedling on the few survivors. Substrate and sowing depth significantly affected germination percentage $[P<0.0001$ for both (Figs. 1 and 3 )], as did the substrate $X$ sowing depth interaction $(P<$ $0.0001)$. Pairwise contrast of the effects of the different treatment combinations on germination after 3 months shows the combined treatment of sand and surface sowing to significantly reduce germination percentage compared with all other combinations $(P \leq 0.0001)$. Contrasts of treatment effects after 3 months show a significant reduction in leaf emergence when seeds were sown at the surface $(P<0.0001)$. Survival after 7 months was significantly reduced for seeds sown in sand instead of potting medium $(P<0.05)$ and seeds sown at the surface $(P<0.05)$. Number of leaves per surviving seedling was not significantly affected by substrate or sowing depth [ANOVA model $P=$ 0.07 (Fig. 2)].

BUCCANEER PALM EXPERIMENT. Seeds sown in the potting mix exhibited the greatest percent germination $(59.7 \%)$ and longest leaf length (16.0 cm average), whereas those sown in perlite showed the least percent germination $(34.4 \%)$ and shortest leaf length $(8.42 \mathrm{~cm}$ average). Seeds sown in perlite showed the highest percent mortality $(84.2 \%)$. Substrate type significantly affected germination rate $[P=0.0009$ (Fig. 3)], pushing up of seedlings $[P<$ 0.0001 (Fig. 1)], and length of the longest leaf $[P<0.0001$ (Fig. 4)]. Pairwise contrasts of the effects of different substrates on germination show the greatest difference between potting mix and perlite $(P=0.0001)$, whereas for pushing up of seeds, the

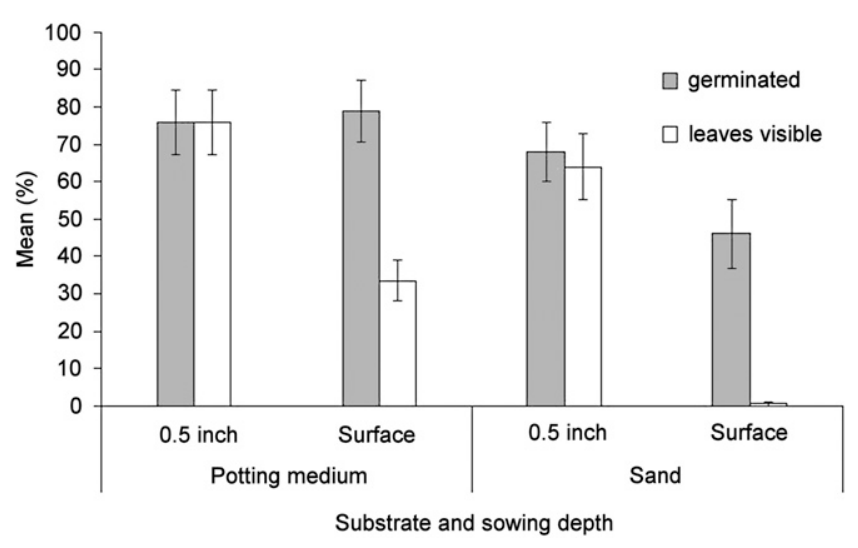

Fig. 1. Mean percent germination and mean percent of yarey palm plants with leaves visible 3 months after sowing at two different depths in two different substrates. Error bars are $\mathrm{sE} ; 1$ inch $=2.54 \mathrm{~cm}$.

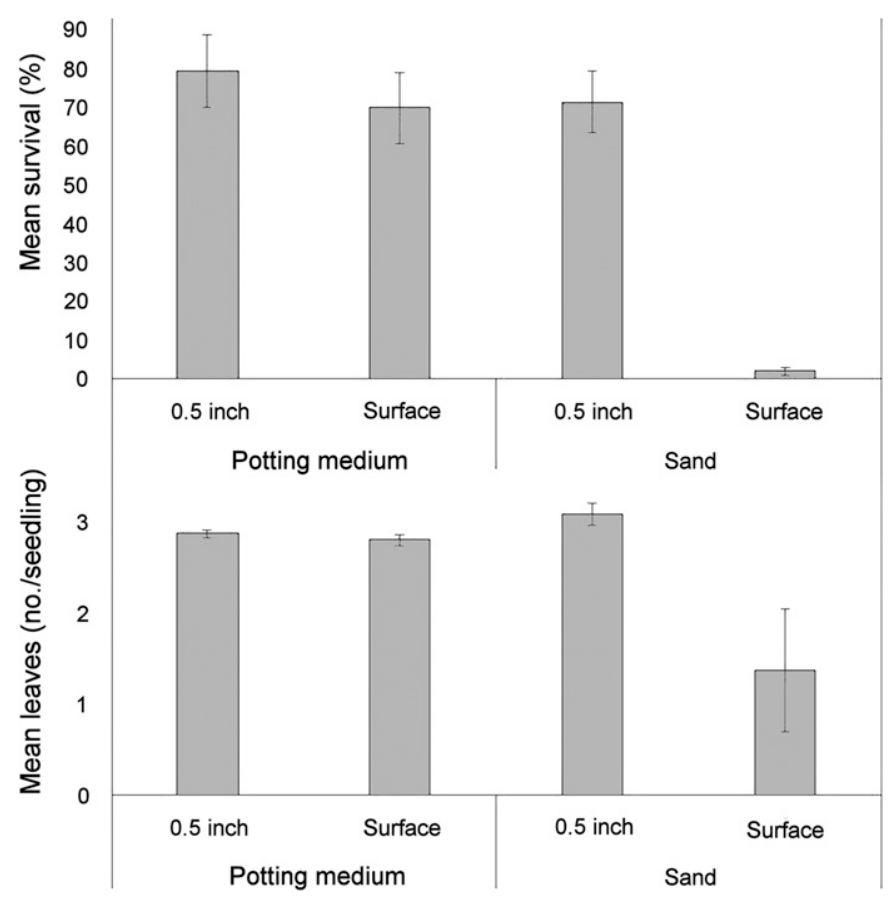

Fig. 2. Mean percent survival of yarey palm after 7 months and mean leaf count per surviving seedling after sowing at two different depths in two different substrates. Error bars are $\mathrm{sE} ; 1$ inch $=\mathbf{2 . 5 4} \mathrm{cm}$.

greatest difference was between potting mix and ceramic $[P=$ 0.0001 (Fig. 5)]. The length of longest seedling leaf differed most between potting mix and perlite $(P<$ $0.0001)$.

SUBSTRATE PHYSICAL PROPERTIES. Physical properties differed among the substrates, with potting mix, potting medium, and ceramic showing greater WHC ranging from $55 \%$ to $60 \%$, and sand showing the least WHC at $15.5 \%$ (Table 1 ). Sand also showed the least porosity, whereas ceramic showed the least air space.
ANOVA models for WHC, air space, and total porosity were all significant $(P<0.0001)$.

\section{Discussion}

Both substrate and sowing depth were found to be important for palm seed germination. The considerable variation in $\mathrm{WHC}$, air space, and porosity among substrates may help explain this variation. The standard nursery potting media both had high WHC, as well as lower air space percentage, whereas perlite and sand 


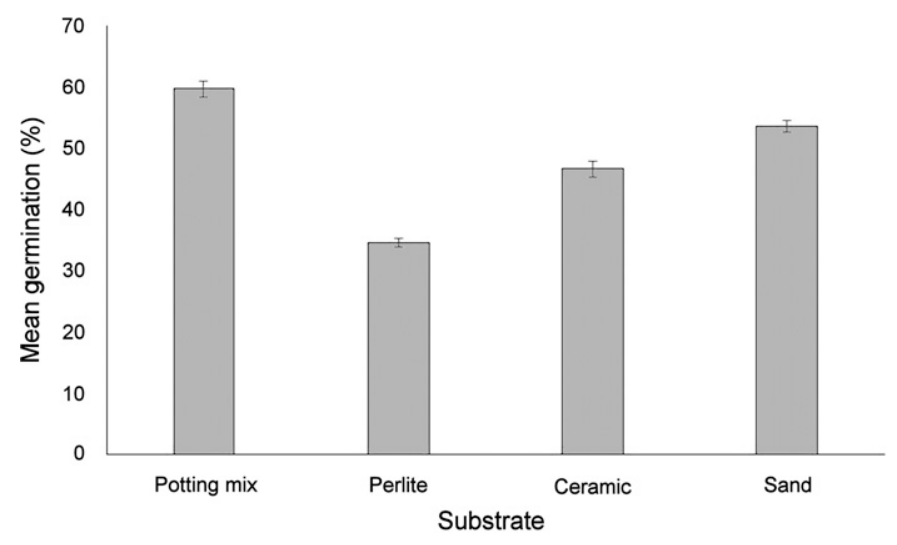

Fig. 3. Mean percent germination of buccaneer palm seeds 8 months after sowing in four different substrates. Error bars are SE.

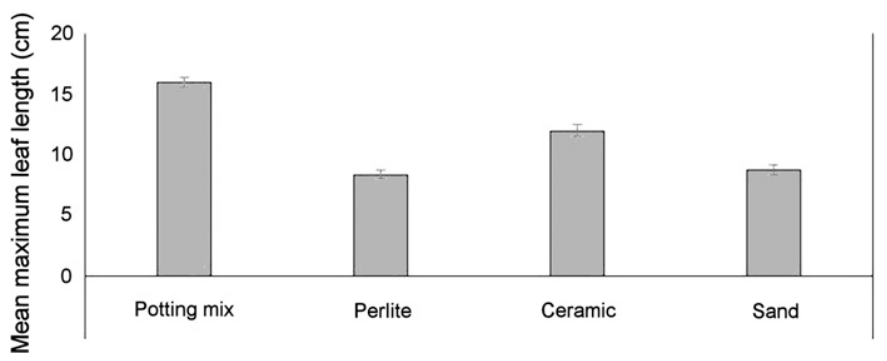

Fig. 4. Mean length of the longest leaf of buccaneer palm seedlings 16 months after sowing in four different substrates. Error bars are SE; $1 \mathrm{~cm}=0.3937$ inch.

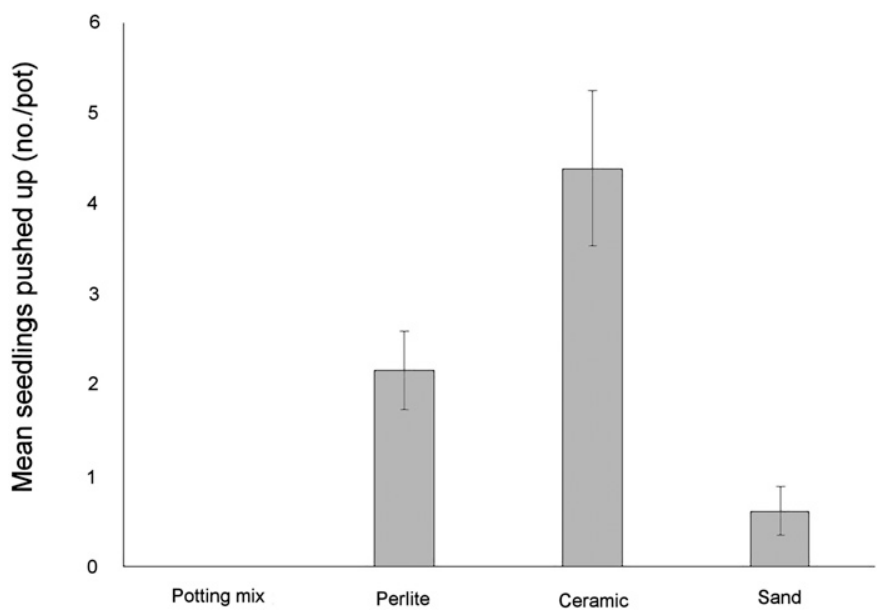

Fig. 5. Mean number of "pushed up" seedlings of buccaneer palm per pot 16 months after sowing in four different substrates. Error bars are SE.

Table 1. Physical properties of substrates used to grow yarey palm and buccaneer palm.

\begin{tabular}{lccc}
\hline Substrate & Water-holding capacity (\%) & Air space (\%) & Total porosity (\%) \\
\hline Potting mix & $58.5 \mathrm{a}^{\mathrm{z}}$ & $11.5 \mathrm{a}$ & $70.0 \mathrm{a}$ \\
Potting medium & $59.8 \mathrm{a}$ & $11.5 \mathrm{a}$ & $71.2 \mathrm{a}$ \\
Perlite & $33.0 \mathrm{~b}$ & $36.8 \mathrm{~b}$ & $69.8 \mathrm{a}$ \\
Ceramic & $55.6 \mathrm{a}$ & $6.5 \mathrm{c}$ & $62.1 \mathrm{~b}$ \\
Sand & $15.5 \mathrm{c}$ & $17.3 \mathrm{~d}$ & $32.8 \mathrm{c}$
\end{tabular}

${ }^{\mathrm{z}}$ Different letters beside the values within columns denote statistically significant differences (Tukey's honestly significant difference) at $\alpha=0.05$. had lower WHC and higher air space percentage. Substrates with higher WHC tended to promote better germination, survival, and growth for both experiments. The higher WHC of potting medium when compared with sand was crucial for germination and survival of yarey palm when surface sown. This is likely due to rapidly drying conditions on the surface of the sand substrate (Broschat and Donselman, 1986). The containers used were relatively tall, which leads the surface areas to be particularly well drained, especially in substrates with larger pores. Shorter containers may lessen this problem but would likely cause more challenges for subsequent seedling growth due to the increased proximity to the perched water table at the bottom of the container (Mathers et al., 2007).

The coarse palm seedlings had more difficulty penetrating the denser inorganic substrates ceramic, perlite, and sand than the less dense organic potting mix, in which no seeds were pushed up. Ceramic proved the most resistant to root penetration. Denser substrates often inhibit plant growth (Passioura 2002) and this may be the case in this experiment since the average maximum length of seedling leaves was significantly higher for the potting mix than for the inorganic substrates.

These experiments indicate that standard nursery mixes are favorable to palm seed germination and growth over the inorganic substrates tested for palm seeds with contrasting germination requirements and times. Shallow burial of seeds is superior to surface sowing for germination, and substrates with a WHC of $50 \%$ or higher allow for better seed germination.

These data illustrate the need for careful substrate selection and careful consideration of sowing method for imperiled palm species. In the case of buccaneer palm, very limited seed production is often noted (SantiagoValentin et al., 2012) and reintroduction efforts that rely on seed-grown outplantings (Maschinski and Duquesnel, 2007) will require maximum genetic diversity for long-term success (Fotinos et al., 2015). Ensuring that nursery methods do not create an additional genetic bottleneck is therefore essential. 


\section{Literature cited}

Asmussen-Lange, C.B., M. Maunder, and M.F. Fay. 2011. Conservation genetics of the critically endangered round island bottle palm, Hyophorbe lagenicaulis (Arecaceae): Can cultivated stocks supplement a residual wild population? Bot. J. Linn. Soc. 167:301-310.

Broschat, T.K. and H. Donselman. 1986. Factors affecting storage and germination of Chrysalidocarpus lutescens seeds. J. Amer. Soc. Hort. Sci. 111:872-877.

Calonje, C., C. Husby, and M. Calonje. 2010. Germination and early seedling growth of rare Zamia spp. in organic and inorganic substrates: Advancing ex situ conservation horticulture. HortScience 45:679683.

Danielson, R.E., P.L. Sutherland, and A. Klute. 1986. Porosity, p. 443-461. In: A. Klute (ed.). Methods of soil analysis. Part 1. Physical and mineralogical methods. Amer. Soc. Agron., Soil Sci. Soc. Amer., Madison, WI.

Fotinos, T.B., S. Namoff, C. Lewis, J. Maschinski, M.P. Griffith, and E.J.B. von Wettberg. 2015. Genetic evaluation of a reintroduction of sargent's cherry palm, Pseudophoenix sargentii. J. Torrey Bot. Soc. 142:51-62.

Gartner, J.B. 1981. Amendments can improve container growing media. Amer. Nurseryman 153(13):70-73, 76-78.

Griffith, M.P., M. Calonje, A.W. Meerow, F. Tut, A.T. Kramer, A. Hird, T.M. Magellan, and C.E. Husby. 2015. Can a botanic garden cycad collection capture the genetic diversity in a wild population? Intl. J. Plant Sci. 176:1-10.

Hewitt, E.J. 1966. Sand and water culture methods used in the study of plant nutrition. 2nd ed. Tech. Commun. No. 22. Commonwealth Bur. Hort. Plantation Crops, East Malling, UK.

Kay, J., A.A. Strader, V. Murphy, L. Nghiem-Phu, M. Calonje, and M.P. Griffith. 2011. Palma corcho: A case study in botanic garden conservation horticulture and economics. HortTechnology 21:474-481.

Kosmidis, I. and D. Firth. 2009. Bias reduction in exponential family nonlinear models. Biometrika 96:793-804.

Maschinski, J. and J. Duquesnel. 2007. Successful reintroductions of the endangered long-lived sargent's cherry palm, Pseudophoenix sargentii, in the Florida Keys. Biol. Conserv. 134:122-129.

Mathers, M.H., S.B. Lowe, C. Scagel, D.K. Struve, and L.T. Case. 2007. Abiotic factors influencing root growth of woody nursery plants in containers. HortTechnology 17:151-162.

Murphy, V., K. Moore, M.P. Griffith, and C. Husby. 2013. Improving conservation through cultivation: Nine container substrates influence growth of a rare cycad, Zamia pumila L. HortScience 48:11681172 .

Namoff, S., C.E. Husby, J. FranciscoOrtega, L.R. Noblick, C.E. Lewis, and M.P. Griffith. 2010. How well does a botanical garden collection of a rare palm capture the genetic variation in a wild population? Biol. Conserv. 143:11101117.

Passioura, J.B. 2002. Soil conditions and plant growth. Plant Cell Environ. 25:311-318.

Riffle, R.L., P. Craft, and S. Zona. 2012. An encyclopedia of cultivated palms. 2nd ed. Timber Press, Portland, OR.

Rodríguez-Peña, R.A., B. Jestrow, A.W. Meerow, T. Clase, F. Jiménez- Rodríguez, M.P. Griffith, E. Santiago-Valentín, J.A. Sustache-Sustache, and J. FranciscoOrtega. 2014. Genetic diversity and differentiation of Pseudophoenix (Arecaceae) in Hispaniola. Bot. J. Linn. Soc. 176:469485 .

Santiago-Valentin, E. J. Sustache, J. FranciscoOrtega, C. Figueroa-Hernandez, J. FuemeroCaban, and P. Griffith. 2012. Pseudophoenix sargentii on Mona Island: Conservation survey and a new discovery. Palms 56: 78-90.

Veloz, A., B. Peguero, T. Clase, and A.G. Fuentes. 2013. Estudio preliminar sobre la distribución, germinación, usos y el estado de conservación del Yarey, Copernicia berteroana Becc. (Aracaceae) en la República Dominicana. Moscosoa 18:57-84.

Warren, S.L. and T.E. Bilderback. 1992. Arcillite: Effect on chemical and physical properties of pine bark substrate and plant growth. J. Environ. Hort. 10:63-69. 